\title{
James Bartlett Edmonson and the Mid-Twentieth-Century Crusade against For-Profit Colleges: An Episode of Ignorance-Making in the United States
}

\author{
A. J. Angulo \\ University of Massachusetts Lowell
}

\begin{abstract}
The nineteen-fifties - a decade of civil rights litigation, Cold War intrigue, and red scare McCarthyism - was also a period racked with controversies over for-profit colleges and universities (FPCUs) in the United States. This paper explores the work of James Bartlett Edmonson and his circle of mid-twentieth-century FPCU critics. Edmonson, a School of Education dean at the University of Michigan during the nineteen-fifties, became one of the most prominent voices against what he described as "shysters" and "sheepskinners" in proprietary higher education. His work exposing FPCU fraud, corruption, and predatory schemes at the national level won him allies at the National Education Association and the Federal Trade Commission. It also created powerful enemies among independent college associations, home study groups, and religiously affiliated institutions. This paper contributes to the literature by engaging with an underdeveloped episode in higher education history and by locating this case study within the emerging field of ignorance studies. Sources for this study were drawn from the James B. Edmonson Papers, Bentley Historical Library, University of Michigan; Research Division Collection, National Education Association, Gelman Library, George Washington University; and published primary source documents in state and national periodicals.
\end{abstract}

\section{RÉSUMÉ}

Les années 1950 - une décennie de litiges en matière de droits civils, d'intrigue de la Guerre froide, et de " peur rouge " maccarthyste—ont aussi été une période marquée par les controverses sur les collèges et les universités à but lucratif (FPCU) aux États-Unis. Cet article explore le travail de James Bartlett Edmonson et son cercle de critiques des FPCU au milieu du $20^{\text {e }}$ siècle. Doyen de l'École d'éducation de l'Université du Michigan dans les années 1950, Edmonson est devenu l'une des voix les plus importantes contre ce qu'il qualifiait de "shysters » et de "sheepskinners " dans l'éducation supérieure à but lucratif. Son travail révélant la fraude, la corruption et les procédés prédateurs des FPCU au niveau fédéral lui a permis de trouver des alliés au sein de la National Education Association et de la Federal Trade Commission. Il s'est également fait des ennemis puissants parmi les associations de collèges indépendants, les groupes d'éducation à domicile, et les établissements d'affiliation religieuse. Cet article 
contribue à la littérature en abordant un épisode méconnu de l'histoire de l'éducation supérieure et en situant cette étude de cas dans le champ émergeant des études de l'ignorance. Les sources de cette étude sont tirées des James B. Edmonson Papers de la Bentley Historical Library à l'Université du Michigan; de la Research Division Collection, National Education Association, de la Gelman Library à l'Université George Washington; de même que de sources primaires publiées dans des périodiques nationaux ou d'États fédérés.

James Bartlett Edmonson enjoyed solving problems. He launched his career by working on the kind faced by high school teachers in Michigan in the 1900s and 1910s. During this period, he taught at the secondary school level and served as a school administrator. After he joined the education faculty at the University of Michigan in 1914 and moved into the dean's office fifteen years later, Edmonson continued a career-long interest in school-based problems. As a professor and dean, he published Problems in Secondary Education (1923), Citizenship and Occupations through Problems (1931), and Civics through Problems (1935). Edmonson advanced this program of scholarship until his retirement in 1953. If the volume of correspondence now housed in the University of Michigan's Bentley Historical Library is any measure, his desk was awash in problems right up to his death in $1954 .^{1}$

Of all the problems Edmonson studied during his forty-eight year career in education, the one that stirred his passions the most was the problem of for-profit colleges and universities (FPCUs). He spent the last decade of his life writing, presenting, and organizing against the sector. His final five years were spent serving as the chair of a National Education Association (NEA) committee "designed to correct the conditions responsible for the existence of an 'underworld" of for-profits. As the oldest and best-known education association in the US, the NEA gave Edmonson a national platform. He leveraged that platform to raise awareness about the FPCU industry that, as he saw it, posed one of the greatest threats to the integrity of American higher education. $^{2}$

Although Edmonson has recently received scholarly attention in Diploma Mills (2016), much of his work organizing a mid-twentieth-century campaign against forprofits remains largely unexplored. ${ }^{3}$ He led a circle of scholars, administrators, and policy-makers that committed itself to raising awareness about unsavoury aspects of the industry, and its members didn't mince words. Edmonson viewed the sector as shot through with owners and operators who behaved liked "sheepskinners," "shysters," and "racketeers." Those in his circle wrote of an underworld in education created by such institutions. Some railed against what they considered fake colleges which had become prevalent in the post-war period. Others blasted the so-called charlatans and "psycho-phonies" who led them. Still others worried about the degrees for sale advertised by the rapidly expanding sector of diploma mills. In short, these individuals passionately believed for-profits were doing far more harm than good, and they were not alone. Their observations reflected a nationwide, but until recently overlooked, response to FPCUs in US history. ${ }^{4}$

This article on Edmonson's campaign offers both a substantive and an interpretive addition to the case presented in Diploma Mills and in standard accounts of post-war 
higher education. The substance of Edmonson and his group's observations, as explicated in this study, draws on a variety of previously unused or understudied sources. These sources include archival documents, government reports, and published articles from mid-twentieth-century America. Collectively, they respond to the still sizable gap in the existing account of for-profit higher education history. ${ }^{5}$ Historians like Roger Geiger and John Thelin have touched on the general topic in their sweeping narratives, but they have focused on different periods. Geiger has limited his analysis mostly to the rise of for-profit law and medical schools in the nineteenth century, and Thelin has called attention to FPCUs established at the end of the twentieth century. ${ }^{6}$ Other scholars, like Glenn Altschuler, Stuart Blumin, and Kathleen Frydl, have focused on political developments in the mid-twentieth century; but they make no mention of Edmonson's nationwide campaign against for-profit colleges or any other citizen-led responses to FPCUs in this era. ${ }^{7}$

The substance of the campaign described in this article offers a starting point for moving us beyond the familiar post-war narrative - the well-studied civil rights, Cold War, and McCarthy era struggles of the nineteen-forties and -fifties in the US. Edmonson's movement against for-profits updates the narrative in ways that align with history of capitalism scholarship that has recently been generating substantial interest among historians. ${ }^{8}$ Edmonson's group had front row seats to witness the white-hot expansion of the era's FPCUs that triggered a backlash across the country. ${ }^{9}$ In response, they launched a mid-century effort - some called it national crusade - to rein in these institutions. ${ }^{10}$ They wrote for scholars, policy-makers, and the general public to move them to action. They wrote for audiences in the US and abroad to widen their impact. And almost all of them wrote because they were scandalized by unscrupulous behaviour in the post-war for-profit sector. With the full extent of their national campaign missing from American mid-century historiography, the Edmonson campaign adds substantive internal and external history of higher education perspectives.

But this article also identifies an opportunity to explore a recent interpretive breakthrough left unexamined by Diploma Mills and other research on for-profit colleges. The interpretive framework - known as ignorance studies or, more formally, as agnotology - has inspired a recent burst of scholarship from a wide range of historians, philosophers, anthropologists, economists, linguists, and political scientists. ${ }^{11}$ Several key theoretical and methodological contributions made by agnotologists to date have appeared in the Routledge International Handbook of Ignorance Studies. ${ }^{12}$ How scholars use these contributions varies from field to field, but the organizing principle has to do with the systematic collection and interpretation of data that advance our understanding of ignorance. As described in the Routledge handbook, researchers typically employ methods that systematically exclude certain data considered "chronically and eminently ignorable" because they fail to speak to existing approaches to constructing research questions. ${ }^{13} \mathrm{With}$ the emergence of agnotology, researchers across the scholarly spectrum have come to recognize the absence of ignorance-making as a basis for researchable questions in their fields. As a result, scholars have begun reworking their methods and procedures for data collection to advance a better understanding 
of how ignorance is produced, diffused, maintained, and regulated in society. These advances have been guided by agnotology's interpretive framework, which organizes socially-constructed ignorance into three categories: naive (that is, not yet learned), passive (not yet studied), and active (deliberate and systematic). ${ }^{14}$

This article introduces Edmonson's mid-twentieth-century campaign as an entry point for accessing a prime episode in the history of ignorance-making. The movement led by Edmonson observed how FPCUs employed all three patterns of ignorance-making — naive, passive, and active — to enhance their standing, obscure their primary purposes, and improve their economic fortunes. Edmonson began his work organizing against the sector out of concern over the need to protect unsuspecting or naive World War II veterans who received GI Bill support and were exposed to inducements from for-profit colleges. He warned state lawmakers of the need to overcome their resistance, or passivity, towards investigating the full extent of known but understudied predatory practices used by FPCUs. And Edmonson reserved his sharpest criticism for the actual, or active, for-profit practices he believed deliberately misled students, taxpayers, and government officials.

The significance of this episode and ignorance-making framework for historical analysis is threefold. First, it challenges historical assumptions that the GI Bill was a nearly unimpeachable success in the diffusion of knowledge and the democratization of college access. Edmonson led a nationwide campaign that suggested the opposite for veterans enrolled at thousands of fly-by-night FPCUs that appeared after the bill's passage. Second, it replaces, at least in terms of this episode, economistic views about how rational, enlightened, self-interested individuals are an indispensable force driving markets. In the case of the mid-twentieth-century for-profit college market, Edmonson's observations point to a far more profoundly important role for ignorance and ignorance-making in the history of capitalism. And third, it broadens the scope of existing agnotological research to include education as a setting worthy of ignorance study. This article offers an education-based point of departure for agnotologists who have gravitated towards and gained distinction for research on science and public policy issues, such as tobacco, asbestos, and climate change.

All three points of significance - for higher education history, history of capitalism, and agnotology — unfold in Edmonson's campaign, which began with the enactment of the GI Bill and ended with his death in 1954. He argued from the start that the public could not afford to remain, as agnotologists would now describe it, naive, passively ignorant, or actively misled when it came to FPCUs. He took aim at patterns and processes of ignorance-making that he viewed as obscuring fraud and inherent conflicts of interest within the for-profit industry. Edmonson called attention to FPCUs by organizing a small band of collaborators and ultimately building a nationwide network of supporters. Although he was not the only one of his generation to mobilize others against "fraud schools," Edmonson had his eye on enlisting policy-makers from coast to coast. His goal was to increase regulatory standards by coordinating FPCU policy in every state. Along the way, he gained a reputation for identifying a significant problem in higher education and spearheading a movement to rein in diploma mills across the country. ${ }^{15}$ 


\section{The GI Bill and the For-Profit Sector}

Edmonson launched his crusade shortly after the passage of the Servicemen's Readjustment Act of 1944, when little was known about what impact the new law would have on higher education. This legislation, also called the GI Bill, provided a way to ease the transition of World War II veterans back into civilian life. The federal government subsidized home mortgages, provided veterans with a monthly stipend for up to a year, and covered full tuition as well as living expenses for education and training. More than 2 million veterans went to college and another 5.5 million enrolled in job-skills programs through the GI Bill. Total enrolments doubled on campuses in the US. In the immediate post-war period, veterans accounted for as much as 49 per cent of the overall higher-education student body. Edmonson lived through a dynamic period of expansion at the University of Michigan as a result of the GI Bill. The campus at Ann Arbor, like virtually all other major campuses, faced intense pressure to meet the increased demand. As enrolments skyrocketed, the university had to invest heavily in creating the infrastructure necessary to handle all the growth. New buildings for classrooms, laboratories, and residence halls sprang up. New professors and programs appeared in the catalogue. The GI Bill, in short, provided financial support for college-going veterans and physically transformed the institutions they attended. ${ }^{16}$

During Edmonson's tenure as dean of the School of Education, the University of Michigan benefited from the influx of new, non-traditional students. With sizable increases in enrolments came increases in funding and program development. Construction of dozens of new campus buildings got underway, and the number of education students alone rose by 300 per cent during the decade following the passage of the GI Bill. Although busy managing this growth, Edmonson worried about the broader impact of the GI Bill. He believed it had the potential to unleash a torrent of illegal and unethical behaviour in for-profit post-secondary education. ${ }^{17}$

Within months of the veteran's bill becoming law, Edmonson fired the first salvo of his crusade with a publication called "Gypped! G.I. Joe Must Be Protected against Low-Grade Colleges." In the article, he focused on the naïveté of veterans about forprofit colleges and the active efforts by FPCUs to mislead prospective students about the industry. Edmonson warned that longstanding patterns of fraud in the sector were not widely known. Citing work from as early as the 1920s, he cautioned readers about "sheepskinners" who operated proprietary institutions without endowment, property, faculty, admissions requirements, or "bona fide courses, either residential or nonresidential." As Edmonson saw it, these institutions had not gone away and the GI Bill would only make matters worse by inspiring the creation of many more diploma mills. He blasted for-profits for tailoring false, ignorance-producing advertisements aimed at unsuspecting veterans. "Will the necessary steps be taken," he asked, "to prevent returning veterans from enrolling in low-grade colleges? Unless prompt action is instituted, many veterans will waste their time and money in attendance at so-called higher institutions from which credits are worthless. Rumors are abroad that some of these institutions are hoping to flourish through the enrollment 
of veterans under the GI Bill of Rights." The article underscored concerns that stood at the intersection of unsuspecting veterans and predatory for-profits. ${ }^{18}$

Edmonson's “Gypped!" not only identified naive and active agnotological problems with FPCUs, it also revealed his concern over what we would now call passive forms of ignorance-making. He chided his peers in traditional higher education for passively ignoring the problem. By failing to take an interest in for-profits, most faculty and administrators of the era knew little of diploma mills and their practices. He also considered lax oversight of the industry as evidence of passive ignorance about for-profits among state-level policy-makers. These government officials, in his experience, tended to have some understanding of the public policy issues at stake but chose inaction due to competing interests. To counter this passivity, Edmonson recommended the establishment of standing committees that would investigate the "underworld of higher education." These committees would review the qualifications of faculty hired by these post-secondary institutions (Did they have adequate training? Does the for-profit have a sufficient number to offer the courses advertised?). They would also inspect their libraries and laboratories (Do they adequately reflect the needs of the programs announced in their flyers? Would they fulfill the programmatic needs listed in the catalogues?). And, finally, Edmonson charged these proposed committees with assessing the accuracy of claims made by institutions about accreditation, program offerings, and transferability of credits for certification (Do peer institutions accept their credits? Do state licencing agencies recognize their graduates?). These recommendations came out of a desire to prompt scholars and lawmakers to learn more about diploma mills and take policy action against them. ${ }^{19}$

Through "Gypped!" Edmonson spoke directly to veterans, academics, policymakers, and FPCU operators. He wanted to inspire the public to demand improved for-profit college regulations at the state level. While the article outlined a call to action, he later discovered that state officials barely noticed. What Edmonson did not know at the time, however, was that "Gypped!" would become the starting point for his nearly decade-long crusade against fraudulent for-profits. ${ }^{20}$

During the four-year period after "Gypped!" was written, government reports and increasing levels of litigation began to confirm Edmonson's early warnings about the FPCU industry's rapid expansion and ignorance-making strategies. There were less than 2,000 for-profits operating in the US the year president Roosevelt signed the GI Bill into law. By the end of the decade, that number had ballooned to more than 7,500. Thousands of brand-new institutions appeared virtually overnight, taking officials at the state and federal level by surprise. ${ }^{21}$ Policy-makers in states like Illinois, Maryland, Michigan, New Jersey, New York, Oregon, Pennsylvania, and elsewhere reported on an escalating number of complaints within their borders. Citizens' groups in Illinois had long demanded action against proprietary schools that peddled poor instruction through misrepresentation as well as "questionable contracts and exorbitant fees." These were places where naive students were being victimized because of inaction and passivity among lawmakers. ${ }^{22}$ Officials in Maryland, meanwhile, witnessed a significant uptick in fraud activity as nearby states tightened regulations on for-profits. Reports from Massachusetts described having already contended with 
"several flagrant examples of such abuses." 23 And New Jersey state education officials began experiencing difficulty keeping pace with "many malpractices on the part of private trade schools." ${ }^{24}$ Cases in New York, Oregon, and Pennsylvania all followed a similar pattern: poor quality instruction, false claims and misrepresentation, and repeated complaints filed by unsuspecting students and taxpayers. ${ }^{25}$

When the for-profit industry's boom reached New Mexico, regulators there decided not to act. Despite receiving complaints from its citizens, the state passively ignored the issue. According to New Mexico's Board of Educational Finance, the state had "no machinery for the control or supervision of private degree-granting institutions." Although the agency was aware of illegal FPCU practices, officials declined to investigate further and decided "there is nothing that can be done until the Federal Trade Commission finds some point at which it can take hold of the case." Since the GI Bill had left supervision of these institutions to state agencies and lawmakers, each state determined how much they would allocate towards FPCU oversight. For citizens of New Mexico during this era, those resources never appeared. ${ }^{26}$

While state agencies struggled to keep up with complaints and supervisory expenses, members of Congress passed amendments to the GI Bill in 1946 and 1949 to curb well-known FPCU abuses. The amendments targeted on-the-job training fraud, misuse of GI Bill funds, and poor quality instruction. They also removed "avocational or recreational" studies from the list of approved GI Bill-funded programs. ${ }^{27}$

To Edmonson, government responses to the FPCU industry's expansion and ignorance-making abuses were too little and too late. Thousands of newly-created institutions now held a substantial place in the higher education landscape. With GI Bill funds in their pocket, millions of students attended, wanted to attend, or were alleged to attend these institutions. Tens of millions of taxpayer dollars now went towards the for-profit sector, either directly, through student enrolments, or indirectly, by way of new state-level supervisory expenditures. Given state government reports of the late nineteen-forties, illegal behaviour and ignorance-making strategies coming from the for-profit sector were no longer hypothetical, as Edmonson described it in "Gypped!" States now had to respond to cases of FPCU fraud against unsuspecting veterans and public coffers. But with each state devising its own regulatory framework, an uneven collection of policies began to emerge. Despite growing recognition of FPCU problems, right through to the end of the decade no one had yet come forward to lead an effort to coordinate the design, development, and implementation of for-profit college policies at the state level. ${ }^{28}$

Edmonson decided to take a shot at it in 1949. By then, he had gained some attention for identifying how fraud and ignorance played out for veterans, states, and the FPCU sector. The "Gypped!" article had, during the late nineteen-forties, attracted a growing professional and popular readership. The Association of American Colleges (AAC) circulated it to its membership, which comprised six hundred liberal arts colleges. AAC representatives had a vested interest in the problem of fake institutions of higher education and likely gave Edmonson's work a sympathetic reading. Guy Snavely, executive director of the association, encouraged his colleagues to learn all they could about for-profits. "These schools are not interested in veterans," 
warned Snavely, "they just want his $\$ 500$ [approximately $\$ 6,500$ in current dollars]." The Edmonson article also appeared in the New York Times as part of a story on fake colleges. It cited "Gypped!" when discussing how for-profits "wait to mulct G.I. students" by taking advantage of their naïveté. ${ }^{29}$

While stepping up his campaign, Edmonson learned of others committed to raising awareness about how the FPCU industry benefited from multiple levels of ignorance. Francis J. Brown, a New York University sociology professor and member of the American Council on Education (ACE), presented and published on the liabilities that would result from remaining naive about the sector. Brown warned about the rash of new FPCUs founded to exploit veterans. The ACE consultant called out commercial colleges for receiving $\$ 500$ for so-called intensive programs that ran for six weeks. Brown concluded that it was no accident the FPCU fee of $\$ 500$ matched the total allowable tuition stipend given annually to veterans through the GI Bill. The American Medical Association (AMA) pursued FPCUs as well, creating a special committee to warn state governors of the need to investigate unscrupulous for-profit medical schools. Members of the AMA expressed special concern about lobbying efforts underway from the sector that ignored medical training standards. They anticipated that unqualified proprietary schools would advance strategies designed to win state-level recognition and the approval necessary to gain access to GI Bill funding. Edmonson kept a file on these kinds of concerns expressed about the for-profit industry. He knew that the AAC, AMA, ACE, and New York Times all shared a common interest in raising awareness of the potential dangers posed by FPCUs. ${ }^{30}$

What was still missing, however, according to Edmonson, was a coordinated effort across states designed to address the naïveté of veterans, passivity of state lawmakers, and active predatory practices of the for-profit sector. The lack of regulatory uniformity throughout the country made it difficult to rein in diploma mills. These institutions could move from state to state in search of favourable - meaning weak or non-existent - regulatory environments. Edmonson wanted to know how each state intended to handle these institutions. He had a hunch, based on reports and correspondence, that only a few had penalties for FPCU operators guilty of false advertising and ignorance-producing misrepresentations. These operators could make unfounded claims about program offerings and employment prospects to prospective students with little or no consequence. For these reasons, Edmonson turned his attention to state level officials who had taken a passive, or lax, to use his word, approach to chartering and monitoring FPCUs. He assumed most states did not know where to begin. ${ }^{31}$

\section{The Crusade's National Committee}

In 1949, Edmonson took his ideas about the FPCU problem to the National Education Association (NEA). As one of the oldest professional organizations in the US, the NEA offered a well-established national platform. The association, originally founded as the National Teachers Association in the 1840s and renamed in the 1870s, received a charter from Congress in 1906. As the organization's membership 
increased during the first two decades of the twentieth century, the NEA moved to Washington, DC, and created a Representative Association drawn from members of professional associations at the state and local level. Through the Representative Association, the NEA maintained a far-reaching network of associates and commanded the attention of educators across the country. The organization established a loyal base of support by conducting studies on teacher salaries, school finances, school taxation, and general federal aid. These studies were designed to improve education throughout the US. By the time Edmonson approached the NEA in 1949, the association had expanded beyond its original role of serving elementary and secondary education interests. He reached out to Ralph McDonald, the executive secretary of the NEA's higher education department, to make a case for why the country needed leadership in the matter of for-profits. ${ }^{32}$

Through McDonald, Edmonson sent a proposal to the NEA that touched on all three forms of socially constructed ignorance involving for-profits. By proposing a Committee for the Protection of Youth and Adults against Fraudulent Schools and Colleges, Edmonson suggested that there was a need to protect unsuspecting prospective college students, whom he recognized as naive about FPCUs. He recommended protections that involved prodding state lawmakers to learn more about for-profit fraud and to implement policies to counter it. The ultimate goal of the committee would be to legislate away the kind of active ignorance-making strategies used by the FPCU sector to advertise and misrepresent their offerings to veterans. McDonald took the message forward, and two key members of the NEA's higher education division supported the measure: Samuel Miller Brownell of Yale University and Earl Anderson of Ohio State University. Both wanted to see the committee launch a national investigation into FPCUs that would yield state-level policy recommendations. The president of the NEA's higher education division, J. Kenneth Little of the University of Wisconsin, approved the proposal and invited Edmonson to serve as chair of the renamed Committee on Fraudulent Schools and Colleges. By the end of the year, Edmonson had agreed to chair the committee, the NEA had assigned the rest of the committee's membership, and the decade defined by World War II had come to a close. ${ }^{33}$

McDonald recommended taking a few months before calling the first committee meeting, but Edmonson chose not to wait that long. In the second week of January 1950, Edmonson gathered his team in Washington, DC, and got to work during a two-day planning session. Five others joined Edmonson: Frank Hubbard, Paul Ellicker, Worth McClure, John D. Russell, and William L. Pencke. At the time, Hubbard served as director of the NEA's research division; he brought investigation resources to the table. Ellicker and McClure both came from school administration organizations. Ellicker was the executive secretary of the National Association of Secondary School Principals. McClure held the same office in the American Association of School Administrators. What they brought was access to organized audiences that dealt with state-level education policy. Russell held an appointment in the US Office of Education. He could speak to trends in education policy at the national level..$^{34}$ 
Of the five members attending the first meeting, however, Pencke would become Edmonson's most important collaborator. As a trial attorney for the Federal Trade Commission (FTC), he had years of experience litigating against for-profits. This experience led Pencke to call the sector "a cancerous growth on the body of education." In one of Pencke's cases, an FPCU owner - whose only educational credential was a bachelor's degree earned from Princeton before the turn of the twentieth century - taught all the classes and claimed the state had officially approved the institution. A Court of Appeals came to the opposite conclusion: "The petitioner's school is neither a university nor an institute. It has no entrance requirements, no resident students, no library, no laboratory, and no faculty. It has no one teaching anything." In another case, a college stated that "anybody can do that" when probed about the qualifications of its faculty in the area of architecture. With a good education, anyone "could teach the methods given in the textbooks." Pencke's FTC caseload had increased exponentially in the late nineteen-forties, and, as he saw it, the Edmonson committee could bring much-needed national attention to FPCU fraud. With Pencke's experience investigating for-profits, Edmonson would come to rely on him for information about specific institutions and ongoing litigation. ${ }^{35}$

Pencke not only brought legal experience to the committee, but also shared Edmonson's three-part vision of the ignorance-based problem with the for-profit industry: naive students, passive lawmakers, and active FPCU owners and managers. When describing the students attracted to diploma mills, he described them as uninformed about the strategies of unscrupulous operators. The naïveté among American citizens and foreign students made them easy prey for those looking at establishing profitable businesses. His comments about state lawmakers echoed those of Edmonson as well. State and federal investigations had exposed many rackets from time to time, but lawmakers had failed to learn about the breadth and depth of the problem. Too many states, according to Pencke, passively ignored how many of these fraudulent institutions received charters within their boundaries and whether non-profit charters had been used to advance for-profit aims. While "moneys [were] being applied to the salaries" of college operators, states ignored whether these institutions produced evidence of financial responsibility, proper equipment, or "adequate buildings, laboratories, libraries, [and] a faculty of learned men possessing degrees from recognized universities and colleges and fully qualified to teach the subjects in which instruction is offered." As for diploma mills, Pencke depicted their business model as organized around deliberately and systematically deceiving prospective students through "skillful advertisements and even more artfully composed catalogs." Together, these elements — with students, lawmakers, and for-profits at the centre — created a maelstrom of ignorance that allowed "degree merchants," as Pencke called them, to flourish. ${ }^{36}$

When Edmonson called Pencke and the rest of the NEA team together for their first meeting, committee members quickly learned what the chair brought to the effort: more than forty years of experience in education and a passion for finding a unifying solution to FPCU problems. At the start of the meeting, Edmonson distributed a twenty-point list outlining the committee's objectives. All of these points fell under two broad goals. ${ }^{37}$ 
The committee's first goal, he argued, was to counter widespread naïveté about for-profits. His first objective along these lines was to enlist the support of educators and members of professional education organizations. Edmonson wanted the committee to acquaint educators with effective ways of marshalling the services of such agencies as the FTC to process FPCU complaints. He also envisioned disseminating information to variety of groups - academic, professional, corporate, and civic - based on reports coming from state agencies about for-profit fraud, exploitation, and false advertising. His goal was to mobilize support from colleges, employers, and education associations at the state, regional, and national levels by calling attention to fake degrees. By doing this, Edmonson hoped to cultivate support among those in a position to advise students against enrolling in diploma mills, including high school counsellors and principals. Moreover, he included religious organizations among his list of potential allies. Edmonson had in mind the Federal Council of Churches and the American Association of Theological Schools. Given reluctance at the state level towards regulating religious organizations, for-profit theological schools had a particularly bad reputation. Edmonson believed established religious and theological organizations could play an important role in cleaning up the sector. Through each of these objectives, he focused the committee's attention on building relationships to diffuse information across the country and increase the public's understanding of FPCUs. ${ }^{38}$

In addition to countering naïveté and lack of awareness, Edmonson described the committee's second goal: overcoming passivity in state-level policy action. To this end, he explained the need for a comprehensive study of higher education policies in each state. Edmonson wanted the committee to clarify the comparative differences that existed between states when it came to laws and regulations designed to handle fraud schools. With such a study in hand, the committee could then assist states in identifying weaknesses in their legal and regulatory frameworks. By sharing what other states had done to combat FPCU fraud, he believed states with weaker oversight could easily make improvements. The committee's next few action steps would centre on drafting and circulating model legislation for state governments to adopt. He wanted to simplify the process for state lawmakers to propose, pass, and enact laws that would drive predatory institutions out of existence. The committee's remaining tasks - publishing in education journals, enlisting the monitoring support of the Better Business Bureau, expanding the use of the US Department of Justice and the Federal Trade Commission's services, requesting regular reports from state officials about fraud policies, and warning foreigners about diploma mills — all shared a common ring of optimism. For Edmonson, it was just a matter of overcoming ignorance — the naive and passive kind — before states could bring predatory institutions to justice. ${ }^{39}$

Edmonson's drive, goals, and objectives energized the committee. Hubbard committed crucial resources from the NEA's research division so they could immediately begin a survey of state policies. Ellicker and McClure expressed a strong interest in meeting with members of their organizations to discuss the for-profit problem. Russell enlisted the support of the Office of Education, where agency officials had 
already compiled a file on "bogus institutions." And Pencke took the lead in drafting model legislation to distribute to chief school officers, state legislators, and civic groups. The energy coming from the committee gave Edmonson reason to believe the tide would to turn in their favour. For five years, the for-profit sector had benefited from a combination of unsuspecting students, easy GI Bill money, and a lax policy environment. Together, these elements allowed opportunists to generate a boom in the for-profit college market. Edmonson saw the NEA committee as a way to slow down or, more optimistically, roll back the expansion of dubious FPCUs. ${ }^{40}$

As word spread about the NEA's newly established Edmonson Committee, a national network of allies and supporters began to form to warn the public about for-profits and their ignorance-making strategies. William S. Carlson, president of the University of Delaware, contacted the committee about fraud rampant on the east coast. He applauded Edmonson for addressing the "growing menace of 'diploma mills.' " W. F. Dyde, vice-president and dean of the faculty at the University of Colorado Boulder, reported on for-profit fraud in the Rockies. He alerted Edmonson to scam artists at the nearby National University and National Research Institute. Howard H. Pattee, executive secretary of the California Association of Independent Schools, expressed support for the committee. Even though his group represented private non-profit schools, Pattee understood the need to curb abuses at the post-secondary for-profit level. On the religious front, church leaders across the country came forward and identified potentially fraudulent programs. A leader of the First Baptist Church in Dixon, Missouri, had doubts about the College of Divine Metaphysics in Indiana and wondered if it was "one of the questionable kind." A superintendent of missions at the Lutheran Synod of Pittsburgh asked the same about Pike's Peak Bible Seminary. The sheer number of fly-by-night for-profit theological seminaries, however, made it particularly difficult for the committee to keep track of this part of the sector. ${ }^{41}$

Edmonson read these and other queries from across the US as the start of a broadbased movement against problem FPCUs. The volume of correspondence he received suggested that the committee had struck a national nerve. Those who contacted Edmonson and his team frequently asked for advice on how to file claims against forprofit institutions. For a time, the committee attempted to compile a list of diploma mills drawn from these complaints. Edmonson would use the list to conduct an initial screening of the worst offenders, and Pencke would follow up with suggestions on potential legal action. Between the two of them, they mobilized local, state, and national contacts to collect more information. Through the FTC and other agencies, they initiated efforts to shut down predatory institutions. ${ }^{42}$

Within months of the committee's inaugural meeting, Edmonson had reason to celebrate the progress made on their first goal of reducing naïveté and increasing public awareness about for-profits. I. L. Kandel, editor of the national education journal School and Society, commended Edmonson for bringing needed attention to proprietary institutions. "Your committee should know," Kandel stated, "how much damage fake institutions are doing to the reputation of American education abroad." When Edmonson offered to write an announcement for the journal, Kandel expressed strong interest in publishing it. Once in hand, the editor considered the piece 
so important that he decided to give it "first place in the issue to be published." The announcement, titled "Fraudulent Schools and Colleges" appeared in 1950, and gave Edmonson an opportunity to offer advice and promote the cause of the committee. He advised prospective college students to select a reputable institution by consulting local employers about proprietary trade and vocational schools. He walked readers through recent reports of scandals and fraud, and he shared with them the kind of claims that should raise flags for prospective students. "The fraudulent trade schools have many deceptive tricks," he warned, "such as 'short cuts' and the promise of an attractive position for which few persons could qualify. Others offer short cuts for certificates and misrepresent the opportunities for employment. In general, any trade school that promises short cuts or employment for prospective students should be viewed with suspicion." Edmonson also asked readers to help keep track of "gyp" institutions. The call to action came with instructions on how to contact committee members as well as agencies like the FTC about predatory institutions. ${ }^{43}$

Around the time the School and Society article was published, leaders of largescale organizations became aware of the Edmonson Committee and contacted its members directly for help. George L. Johnson, president of the Baptist Foundation in Illinois, turned to Edmonson for advice on doctoral level studies. Given the expanding claims against proprietaries, Johnson wanted an opinion about whether one of the foundation's institutions - Southern Illinois College of the Bible-should consider offering a doctoral program. Harold B. Baker, chairman of the business administration division for General Motors, also reached out to Edmonson from Michigan. He "noted with interest" the NEA committee's work on the troubled forprofit sector of higher education. Baker wondered if Edmonson's team could assist GM with employment applications received by the company. The car executive had seen potentially fraudulent degree claims — as high as the $\mathrm{PhD}$ — cross his desk. A similar story came from Captain Harry F. Gay of the March Air Force Base in California. As with the other queries, Gay needed guidance in separating the wheat from the chaff. "Several of my men," he suspected, "have Degrees from Colleges that I believe are questionable." All of these requests reminded Edmonson and his NEA colleagues of the need to continue making headway in their efforts to reduce naïveté about FPCUs. Widespread abuses by the for-profit sector had become a destabilizing force in American religious, corporate, and military life. ${ }^{44}$

As the Edmonson Committee made progress on the first goal of the crusade - raising public awareness - they also made breakthroughs on the second goal of promoting policy action. As promised, Hubbard devoted resources from the research division at NEA to complete a nationwide survey of state boards of education. Results from the survey gave them insight into the level of passive ignorance maintained by policy-makers about what they knew about for-profits, what they wanted to know about the institutions, and what they needed to know in order to respond to them in their states (Table 1). The responses received by the committee indicated that the situation was worse than anticipated. According to Edmonson, no other major country was as lax as the US in allowing "shyster" schools and diploma mills to sell their degrees to unsuspecting students. ${ }^{45}$ 
Table 1

NEA Nationwide Survey of Forty-Eight State-Level Departments of Education (January 1953)

\begin{tabular}{|c|c|}
\hline Sample Survey Questions & Responses \\
\hline $\begin{array}{l}\text { Is a charter or licence required before an educational } \\
\text { institution can operate in your state at the college level? }\end{array}$ & $16=\mathrm{No}$ \\
\hline $\begin{array}{l}\text { Does a state agency or committee prepare a list of } \\
\text { approved colleges of your state? }\end{array}$ & $13=\mathrm{No}$ \\
\hline $\begin{array}{l}\text { To your knowledge, are there any non-accredited colleges } \\
\text { in your state that offer master's or doctor's degrees by } \\
\text { correspondence in such fields as religion, psychology, } \\
\text { psychiatry, or nature healing? }\end{array}$ & $7=$ Yes \\
\hline $\begin{array}{l}\text { Does your state have adequate laws or regulations for } \\
\text { closing low-grade institutions, especially "diploma mills"? }\end{array}$ & $\begin{array}{l}17=\text { No } \\
5=\text { No reply }\end{array}$ \\
\hline $\begin{array}{l}\text { Does your state require all higher education institutions, } \\
\text { except those accredited by a regional or state agency, to } \\
\text { file with your office copies of catalogues, announcements } \\
\text { or degrees, and course requirements? }\end{array}$ & $\begin{array}{l}32=\text { No } \\
3=\text { No reply }\end{array}$ \\
\hline $\begin{array}{l}\text { Does the problem of low-grade schools exist in your } \\
\text { state? }\end{array}$ & $\begin{array}{l}10=\text { Yes } \\
5=\text { No reply }\end{array}$ \\
\hline $\begin{array}{l}\text { Which of the following services, if any, might your office } \\
\text { desire from the NEA Association for Higher Education in } \\
\text { efforts to close low-grade institutions? (Types of services } \\
\text { are indicated by the replies.) }\end{array}$ & $\begin{array}{l}22=\text { Lists of LG schools } \\
28=\text { Plans for eliminating } \\
\text { LG schools in other states } \\
29=\text { Effective legislation } \\
27=\text { Procedures for college } \\
\text { accreditation in other states }\end{array}$ \\
\hline
\end{tabular}

Note: LG = Low Grade/Fraud Colleges.

Source: James B. Edmonson, "Responsibility for Diploma Mills," Higher Education

(January 1954): 88-89.

The survey's findings confirmed that overcoming passivity at the state level and coordinating for-profit higher education policy would pose a significant challenge. The majority of survey respondents knew they were largely ignorant about what other states were doing to address FPCU problems. At the same time, respondents expressed an interest in filling this known gap in what they knew. Officials in seventeen states mentioned that improving legislation to prevent the operation of low-grade colleges was both desirable and feasible. These same officials, however, noted that their offices had little or no control over the granting of charters or licences. The gap between what these officials knew and what they wanted to know inspired Edmonson to work closely with Pencke in drafting a legislative blueprint for lawmakers to sponsor at the state level. The blueprint proposed stricter state laws and regulations, particularly with for-profit college licensing, chartering, and advertising. It also proposed 
laws that demanded evidence of the value of non-accredited colleges and universities. The goal was to produce a political culture willing to shame diploma mills. But Edmonson believed none of the laws would work without implementing the most important recommendation of all: increased and aggressive state-level prosecution of owners and operators of fraudulent institutions. He recommended that states should begin filing criminal charges against "sheepskinners" and "shysters." Without putting offenders in jail, he believed, predatory practices would continue. ${ }^{46}$

As they worked to reduce public naïveté and overcome state policy inaction, Edmonson and his committee could have enlisted the support of accrediting agencies. Instead, they chose to communicate directly with state governments, because accreditation was not the central problem. Reports received by the committee from across the country indicated that non-accredited for-profit colleges aggressively recruited veterans with their GI Bill funding. For-profits targeted GIs who knew little about the difference between accredited and non-accredited colleges. For these reasons, Edmonson chose to focus on states - their legislators and education agencies. They alone had the authority to close problematic, non-accredited FPCUs that had successfully advertised their way into the GI Bill market. The NEA survey had shown that "most of the State educational officials do not have much information regarding nonaccredited higher institutions," but that they wanted "evidence of the value of degrees and certificates issued by nonaccredited institutions." Accrediting agencies could help with lobbying states for stricter laws, but not with the passing or enforcement of the laws themselves. ${ }^{47}$

With state officials in mind, the Edmonson Committee turned its attention towards creating a model bill that would protect unsuspecting veterans and mobilize lawmakers. It did not take them long, and the bill they circulated received favourable responses from executives at the Oklahoma State Regents for Higher Education, the American Council on Education, and the National Association and Council of Business Schools. These executives appreciated the "high contribution" it made towards eliminating "fake colleges," and they applauded the "general objective." ${ }^{48}$ Others who learned about the effort from abroad wanted to know more. A German official, for instance, wrote to the committee asking for advice on how Europeans should distinguish between a diploma mill and a legitimate institution. Were there no laws, like there were in Europe, protecting citizens from unsanctioned institutions? This was no trivial question. By the start of the nineteen-fifties, the number of for-profits that had received Veterans Administration (VA) approval hovered around 9,000. A full two-thirds of these had been established as a result of the GI Bill during the five-year period after its passage. ${ }^{49}$

The model bill, nevertheless, received a cold reception from other groups. Among the staunchest critics were those from Bible colleges and theological institutions. Many, cautioned one of Edmonson's supporters, are "associated with off-brand religious denominations and seek refuge in their constitutional rights of religious freedom when attacked in the courts." 50 Fort Wayne Bible College fit such a description. The college's president, S. A. Witmer, thought the bill was too restrictive and not conducive to the "right of propagating religious faith." He appealed to 
"freedoms inherent in our democracy" as the reason for his resistance to penalties against and supervision of religiously affiliated for-profits. He called Edmonson's bill "un-American and undemocratic," at a time when such accusations caught the attention of people like US Senator Joseph McCarthy. Religious liberty, as Edmonson's circle of colleagues had warned, protected fraudulent institutions and provided them with a constitutional defence against attempts to eliminate them. Religiously affiliated for-profit colleges might have defended their institutions as expressions of faith protected by the First Amendment, but Edmonson was a skeptic. He had received an overwhelming number of allegations about profit-driven colleges defrauding students looking for religious instruction. It was among the most common complaints Edmonson received. Ignorance-making in these cases operated on multiple levels: naïveté among the public about how the principle of religious liberty could protect unscrupulous proprietary institutions; passivity among national religious organizations and state agencies about the need to monitor or regulate the sector; and active ignorance-making by proprietors about their institutional offerings, facilities, and faculty. Edmonson fought what he saw as abuses of religious freedom by appealing to mainstream organizations like the American Association of Theological Schools. But he and his circle continued to receive a disproportionate number of letters about short-lived, off-brand religious colleges that based their right to exist on the constitution. ${ }^{51}$

Despite opposition from religious quarters, Edmonson's campaign against forprofits continued to increase awareness about the FPCU sector. According to the American Council on Education, Edmonson had aroused the public's interest in "the danger of this vicious 'racket.' " A flood of correspondence came to the committee from professors, college administrators, state officials, regional accreditors, military officers, journal editors, and agents of philanthropic organizations across the country. For the most part, they wrote asking about suspected diploma mills or, more generally, about any lists the committee had of fraudulent institutions. These individuals wanted to know if their local institution, often a Bible college or religiously affiliated FPCU, was worthy of the name college or university; or they wanted a complete, nationwide accounting of fraudulent institutions so they could identify those located in their state and region; or they simply wanted to show their support for the committee's work and join them in their effort to curb such institutions, as some expressed it. At the time, these individuals and organizations were not sure who else to turn to for this information. And that was a motivating factor driving Edmonson's campaign. The problem - the absence of any formal, timely, and comprehensive data about untrustworthy for-profits - left the public and policy-makers blind, ignorant, and without guidance..$^{52}$

Between 1950 and 1952, the Edmonson Committee received a strong tailwind from a series of federal investigations into FPCUs and their ignorance-making practices. The VA published a two hundred-page report that identified FPCUs as the source of 78 per cent of GI Bill fraud and deception against the federal government. Such reports led to the closure of hundreds of institutions. The VA identified hundreds more as unacceptable. More than a thousand of these schools reduced their 
tuition fees when asked to disclose financial information. The investigations resulted in enforcement at the national level that recovered millions of fraudulently acquired GI Bill dollars. "There is no doubt," VA officials concluded, "that veterans' education has been an extremely lucrative and profitable enterprise for certain types of business men... [in the] education and training of veterans for which honest value is not being received." ${ }^{33}$ A similar report came from a US House of Representatives committee assigned to study the use of GI Bill funds for education. The congressional report they produced blamed weak regulations and enforcement on the spread of for-profit abuses. Approximately half of a sampling of institutions - consisting of more than six hundred proprietary colleges — engaged in illegal practices. Even more turned up evidence of questionable activities. "Exploitation by private schools," House committee members stated, "has been widespread." 54

During this two-year period, the Edmonson Committee continued to work on its second charge of overcoming passivity at the state level and facilitating legislative action. The federal investigations, and the headlines they made, inspired the committee to redouble its efforts with state governments. But the committee needed funding. Edmonson and his team had relied on modest support from the NEA to sponsor a meeting or two per year. Funds allocated by the NEA's research division had dried up after the state policy survey was completed. As a result, members of this committee personally absorbed costs for their time, effort, travel, and supplies. ${ }^{55}$

Edmonson recognized the problem, and he came up with a plan to fund their campaign against ignorance-making produced by the era's for-profit colleges. At the end of May 1952, he called on Alvin Eurich, vice-president of the Ford Foundation's Fund of the Advancement of Education, for support. "Our committee," his request began, "is not able to make a vigorous drive against 'gyp' institutions because of a lack of funds. At present we have funds for an annual meeting of our Committee but lack money for the implementation of an effective program." Edmonson then went on to outline what his team had left to do. With Ford Foundation support, the committee would meet with higher education accreditors, create and distribute public service announcements about "shyster" colleges, counter FPCU lobbying work at the state level, and conduct investigations into egregious for-profit abuse cases. In other words, Edmonson asked for help to continue working against public naïveté and state policy passivity. To cover travel and material expenses, he asked Eurich for a grant of approximately $\$ 25,000$. Edmonson had considered asking for $\$ 160,000$, but he went with a safer, almost sure-bet figure. ${ }^{56}$

The plan failed. Eurich's reply was gracious, but clear: "Certainly some effort should be made to close these institutions... all of us are impressed with the need to close 'shyster' schools." But funding the Edmonson Committee would be a bridge too far. The Ford Foundation's mission was one of improving and strengthening reputable systems of education, not of attacking or undermining disreputable ones. Citing the Flexner Report and its early twentieth-century study of medical education, Eurich justified the decision by stating that poor quality institutions "were forced to close because of the greatly improved programs in other schools. It is this approach that we are pursuing." The Ford Foundation's reply dampened the committee's prospects. ${ }^{57}$ 
Edmonson and his colleagues, however, pressed on. Despite the lack of funds, they continued to make a personal investment in the campaign against for-profit college fraud. For the next two years, following his exchange with Eurich, the committee continued to distribute information to a national network of concerned educators, state officials, and lawmakers. Through these efforts, they could count several victories on their side of the ledger. They had raised public awareness about problem for-profits. They had conducted a comprehensive survey of state FPCU policies and practices. And they had drafted model legislation for lawmakers to introduce at the state level, where Edmonson believed the battle would be won or lost. "There is a great need," he believed, "for strengthening the legislation in most States so as to protect the public against the tricky and corrupt practices of diploma mills." The committee, moreover, had rallied a national network of allies around the goal of eliminating proprietary fraud and abuse. Edmonson created a pipeline of information that ran directly from this network to the FTC, where institutions were considered for investigation and prosecution. ${ }^{58}$

\section{Conclusion}

Despite its victories, Edmonson's mid-twentieth-century campaign against predatory FPCUs came to an abrupt end in 1954. Edmonson, by then in his seventies, died that year. With him went a one-man crusade, as Arthur Adams, president of the American Council on Education, put it. Without its chair to lead the crusade, the progress made by the NEA committee dissipated. Edmonson had started working on the problem of for-profits around the time Congress passed the GI Bill of 1944, and he lived long enough to establish a national campaign against the FPCU sector's worst offenders. He also lived to see his three main predictions realized, those about the naïveté of veterans, the passivity of state lawmakers, and the active strategies used by for-profits to defraud the public. What he could not have predicted, and what he did not live to see, were the proposals made by Congress a decade later to expand federal student aid programs to all prospective college students. The Higher Education Act (HEA) of 1965, as it became known, was at first silent on the matter of for-profits. But it later became the single most significant economic boon in for-profit college history. ${ }^{59}$

The lessons learned by Edmonson, his committee, and their national network of contacts about student aid for veterans disappeared long before the era of the HEA. If these policy lessons had survived, lawmakers might have avoided repeating past mistakes when making aid available to the for-profit sector. The 1972 HEA reauthorization opened this Pandora's box by giving "proprietary" college students access to subsidized programs. ${ }^{60}$ But the lessons learned earlier were nowhere to be found, and the safeguards preventing the next boom in diploma mill expansion never materialized. As if reciting pages out of Edmonson's original "Gypped!" article, later generations have warned of large-scale fraud in the FPCU sector. Bill Bennett, the US secretary of education in the late nineteen-eighties, commissioned an investigation into for-profits in an era when multiple hundred million-dollar FPCU schemes were 
making headlines. He found the investigation's results conclusive. "Exploitative and deceitful practices," he discovered, "characterize too many proprietary institutions." ${ }^{61}$ In the nineteen-nineties, US Senator Sam Nunn came to the same conclusion after leading another series of studies into and hearings about the industry. The results showed Nunn that all that was needed was to "throw a dart at the board" to find a huge scandal. ${ }^{62}$ The same story was repeated again in the first decade of the twentyfirst century with federal investigations led by US Senator Tom Harkin. "I continue to be amazed by the questionable, and sometimes outright illegal, practices occurring within the for-profit sector," he described. "Critics say that it is only a few bad apples, but we need to take a hard look at the entire orchard." 63

What the Edmonson campaign offers is substantive insight into an overlooked chapter in the history of higher education. It complicates standard assumptions about the GI Bill as a democratizing force in higher education by shifting attention to for-profit college fraud. The campaign identified recurring patterns of FPCU abuses that appeared long before the investigations of the late twentieth and early twenty-first centuries. The perspectives - internal (that is, committee work) and external (the public's responses) - derived from Edmonson's circle underscore the need to recast well-worn assumptions about the GI Bill's successes in diffusing college access. ${ }^{64}$ They also remind us of the opportunity to explore the interplay among education, profits, regulation, and public activism. During the mid-twentieth century, the public's unease with FPCUs was far more prevalent and widespread than has been commonly assumed. Edmonson's campaign over a short period of time created national alliances with individuals and institutions who launched their own efforts. Their separate initiatives, by extension, offer promising opportunities for further historical research. ${ }^{65}$

For historians of capitalism, Edmonson's observations about ignorance-making advance our understanding in two ways. First, ignorance offers a more satisfactory explanation for the rapid rise of industries like for-profit colleges than explanations based on economic rationalism. Ignorance, rather than reason and enlightened selfinterest, guided the decision-making of veterans and lawmakers. As such, agnotology establishes a promising new frontier for historians of capitalism interested in exploring alternatives to standard ideas about market forces and the distribution of scarce resources. Second, ignorance-making as described by Edmonson can inform ongoing discussions among historians about the need to study capitalism "from the bottom up" and from "multiple angles using multiple methodologies." ${ }^{66}$ As these scholars expand their horizons beyond relationships among business, labour, and the state, ignorance-making presents new research opportunities focused on students, education policy-makers, and for-profit college owners. The history of capitalism, in short, would be incomplete without an understanding of FPCUs as well as of those patterns of ignorance that fuelled the sector's development. The mid-twentieth-century campaign against for-profits provides a starting point for advancing historical analyses in both areas.

For agnotologists, the mid-century crusade outlines yet another critical instance of ignorance as a motivating historical factor. It highlights the utility of education as 
a site for exploring ignorance-making, especially for those who associate agnotology with science and public health controversies. ${ }^{67}$ Edmonson's campaign was fundamentally a battle against ignorance-making. He was motivated by the idea of protecting unsuspecting veterans. Agnotologists would define this group of students as naive and unaware of the predatory practices employed by the FPCU sector. Edmonson decried state governments for recognizing for-profit college problems and failing to adequately respond to or look into the matter. Agnotologists would view the absence of state-level investigations into FPCUs as a form of passively maintained ignorance. And the for-profit college fraud itself, in its deliberate and systematic forms, aligns squarely with the agnotological category of active ignorance production. For these reasons, Edmonson's mid-twentieth-century campaign captures all three primary forms of socially constructed ignorance recognized by researchers in the field. The significance for historical analysis is that while agnotologists have valorized the study of fraud, deception, and other ignorance-related topics, historians of higher education have tended to marginalize such topics as secondary to more compelling narratives. As a result, the fraud-based strategies of for-profit colleges have until recently appeared on the historical margins as the work of outliers or the practices of a few bad apples. ${ }^{68}$ Agnotology revises and remakes this history by interpreting ignorancemaking as the motivating factor driving one of the first nationwide campaigns against for-profits in the US. This episode adds to the now-vibrant literature on ignorancemaking as a prime agent — one as powerful as social movements, economic crises, political conflicts, and intellectual advances - in shaping the course of the past and present. Edmonson's campaign identified patterns of ignorance production, diffusion, maintenance, and regulation that have contributed to the rise of today's $\$ 35$ billion FPCU industry. ${ }^{69}$

What Edmonson learned, and what subsequent generations have had to relearn, was that the profit motive in higher education creates significant conflicts of interest. Edmonson observed how these conflicts played out when for-profits focused on short-cuts and oversold promises of gainful employment. In recent years, these strategies have reappeared in surprisingly similar forms that have benefited FPCU owners at the expense of students and the public trust. Consider the recent and pending litigation against such companies as Corinthian, Kaplan, Career Education Corporation, Education Management Corporation, and Trump University. Students, whistleblowers, and shareholders have filed complaints against these institutions for false claims and misleading statements - what agnotologists describe as active ignorance production. ${ }^{70}$ Edmonson recognized the active ignorance-making strategies associated with these kinds of institutions when he called for protecting the public from fraudulent schools and colleges. This problem became the primary focus of his final campaign. He tapped into a timeless public unease with ignorance-making and the profit motive, and his efforts rallied one of the most formidable challenges to the sector in FPCU history. 


\section{NOTES}

1 James Bartlett Edmonson was born in Iowa in 1882. He received a BA in 1906 and an MA in 1910 from the University of Michigan and a PhD in 1925 from the University of Chicago. He held faculty and administrative appointments at Michigan from 1914 until 1953. Edmonson's basic biographical information was drawn from finding aids for the James B. Edmonson Papers, Bentley Historical Library, University of Michigan, Ann Arbor, MI (hereafter, JBEP). For a sampling of Edmonson's problem-centred publications, see the following: Problems in Secondary Education (Bloomington, IL: Public School Publishing Co., 1923); Problems of a High-School Teaching Staff (Bloomington, IL: Public School Publishing Co., 1924); Problems of the High School Teacher (Bloomington, IL: Public School Publishing Co., 1924); and Arthur Dondineau, Citizenship through Problems (New York: Macmillan, 1927); Citizenship and Occupations through Problems (New York: Macmillan, 1931); Civics through Problems: A Social and Governmental Civics (New York: Macmillan, 1935); Practical Problems in Education: One Hundred Problems to Supplement Courses in Secondary Education (Bloomington, IL: Public School Publishing Co., 1939).

2 James B. Edmonson, "Report of the Committee on Fraudulent Schools and Colleges for 1953," 1. Edmonson's publications and correspondence on for-profits differs qualitatively, and is more advocacy-oriented in nature, than his earlier work on other educational problems. See JBEP for a comparison between works before (non-FPCU) and works after (FPCU) the Servicemen's Readjustment Act of 1944, known as the GI Bill. His warnings about for-profits published in Schools and Society issues of the early nineteen-fifties included calls for action and support from readers. No similar calls appear in Edmonson's earlier work.

3 Although Edmonson is mentioned in A. J. Angulo, Diploma Mills: How For-Profit Colleges Stiffed Students, Taxpayers, and the American Dream (Baltimore, MD: Johns Hopkins University Press, 2016), this article offers an explicit analysis of his publications, advocacy work, and relationship with the National Education Association. Given the gap in the historiography on Edmonson and for-profits in the nineteenfifties, this work contributes a novel starting point for further research on the GI Bill, higher education reform, and mid-century for-profit post-secondary education.

4 James B. Edmonson, “'Gypped!': G.I. Joe Must Be Protected against Low-Grade Colleges," The Nation's Schools 35 (February 1945); James B. Edmonson, "The Underworld of Education: Degrees and Diplomas Can Be Bought," Michigan Alumnus Quarterly Review 59 (Autumn 1952); Benjamin Fine, "Fake Colleges Wait to Mulct G.I. Student," New York Times, May 31, 1945, 1; Dell Lebo, "Degrees for Charlatans," The American Psychologist (June 1953); Jhan Robbins, "Exposing the Psycho-Phonies," Collier's, March 22, 1952, 15; Joseph Harsch, "Thar's Gold in Them Ther Schools," Christian Science Monitor, October 27, 1949; James B. Edmonson, "Fraudulent Schools and Colleges," School and Society 72 (July 15, 1950).

5 Archival sources for this study were drawn from the following: James B. Edmonson Papers, Bentley Historical Library, University of Michigan; Research Division Collection, National Education Association, Gelman Library, George Washington University. This article has also relied on a variety of published primary sources from state (for example, Michigan Alumnus Quarterly Review) and national (for example, School and Society) periodicals as well as reports from state and federal agencies (such as Veterans' Affairs).

6 Roger L. Geiger, The History of American Higher Education: Learning and Culture from the Founding to World War II (Princeton, NJ: Princeton University Press, 2014); John R. Thelin, A History of American Higher Education (Baltimore, MD: Johns Hopkins University Press, 2011). Other relevant accounts on for-profits appear in Richard Ruch, Higher Ed, Inc.: The Rise of the For-Profit University (Baltimore, MD: Johns Hopkins University Press, 2003). 
7 Glenn Altschuler and Stuart Blumin, The GI Bill: A New Deal for Veterans (New York: Oxford University Press, 2009), ch. 6; and Kathleen Frydl, The GI Bill (New York: Cambridge University Press, 2009).

8 Until recently, the economic ideology literature has been dominated by geographers (for example, David Harvey, Jamie Peck, and Trevor Barnes) and political economists (for example, Colin Crouch, Monica Prasad, Gérard Duménil, and Dominique Lévy), rather than mainstream historians. Since the 2007-2008 global economic meltdown, however, that pattern has changed. See, for instance, Kim Phillips-Fein, Invisible Hands: The Making of the Conservative Movement from the New Deal to Reagan (New York: W. W. Norton, 2009); Angus Burgin, The Great Persuasion: Reinventing Free Markets since the Depression (Cambridge, MA: Harvard University Press, 2012); and Daniel Stedman Jones, Masters of the Universe: Hayek, Friedman, and the Birth of Neoliberal Politics (Princeton, NJ: Princeton University Press, 2012). Harvard University's history department has also spearheaded the Program on the Study of Capitalism and the Workshop on the Political Economy of Modern Capitalism, which receive support from such sources as the David Howe Fund for Business and Economic History, the Mahindra Humanities Center, Harvard Law School, the Charles Warren Center, and the Harvard Graduate School of Arts and Sciences.

9 White-hot expansion is defined as a 300 per cent increase in for-profits. House Select Committee to Investigate Educational, Training, and Loan Guaranty Programs under GI Bill, US House Report No. 1375 (Washington, DC: Government Printing Office [hereafter GPO], 1952), 12 (hereafter, HSC 52). This report calculated that there were 1,878 FPCUs in operation on June 22, 1944. After the passage of the GI Bill, the number increased to 5,635, representing a 300 per cent increase. According to another report, the jump was much higher. The Report on Education and Training under the Servicemen's Readjustment Act, as Amended from the Administrator of Veterans' Affairs (Washington, DC: GPO, 1950), hereafter RETS, states that there were 8,954 "approved [for-profit] educational institutions" by 1949, 46.

10 Arthur S. Adams to Harlan H. Hatcher, July 23, 1958, JBEP.

11 The most recent wave of ignorance studies can be traced back to Shannon Sullivan and Nancy Tuana, eds., Race and Epistemologies of Ignorance (Albany, NY: SUNY Press, 2007) and Robert Proctor and Londa Schiebinger, eds., Agnotology: The Making and Unmaking of Ignorance (Stanford, CA: Stanford University Press, 2008). These works laid a historical and philosophical foundation for a new, interdisciplinary research program intended to bring all disciplines into the task of analyzing ignorance. The second of the two popularized "agnotology" as the term used for ignorance studies. Philosopher Nicholas Rescher, Ignorance: On the Wider Implications of Deficient Knowledge (Pittsburgh: University of Pittsburgh Press, 2009); historians of science Naomi Oreskes and Erik M. M. Conway, Merchants of Doubt (London: Bloomsbury, 2011); anthropologists Casey High et al., Anthropology of Ignorance (London: Palgrave, 2012): and political economist Philip Mirowski, Never Let a Crisis Go to Waste (London: Verso, 2013) have all drawn on this earlier work. More recently, Matthias Gross and Linsey McGoey, eds., Routledge International Handbook of Ignorance Studies (New York: Routledge, 2015) and A. J. Angulo, ed., Miseducation: A History of Ignorance-Making in America and Abroad (Baltimore, MD: Johns Hopkins University Press, 2016) have added education to the recent thrust of agnotology research.

12 Gross and McGoey, eds., Routledge International Handbook of Ignorance.

13 Mike Michael, "Ignorance and the Epistemic Choreography of Method," in Routledge International Handbook of Ignorance, ed. Gross and McGoey, 87.

14 For more on the three primary forms of ignorance, see Robert Proctor, "Agnotology: A Missing Term to Describe the Cultural Production of Ignorance (and Its Study)," in Agnotology, ed. Proctor and Schiebinger, 1-36. 
15 Fine, "Fake Colleges," 1.

16 David Vacchi and Joseph Berger, "Student Veterans in Higher Education," in Higher Education: Handbook of Theory and Research, Vol. 29, ed. Michael Paulson (Dordrecht: Springer, 2014), 96-99; Kevin Kinser, "GI Bill," in Higher Education in the United States: An Encyclopedia, ed. James Forest and Kevin Kinser (Santa Barbara, CA: ABCCLIO, 2002), 276-279; V. R. Cardozier, Colleges and Universities in World War II (New York: Praeger, 1993), 211-229.

17 The University of Michigan... A Decade of Achievement (Ann Arbor, MI: University Relations Services, University of Michigan, 1956); James B. Edmonson, "Gypped! G.I. Joe Must Be Protected Against Low-Grade Colleges," The Nation's Schools 35 (February 1945): 25.

18 Edmonson, “Gypped!,” 25.

19 Ibid.

20 Ibid.

21 For-profits on Veterans Administration approval lists from 1944 to 1949 itemized in HSC 52, 29.

22 Illinois Legislative Council, Statutory Control of Private Trade Schools (Springfield, IL: Author, 1948), 2. The state of Illinois commissioned the publication of Statutory Control of Private Trade Schools as part of an investigation into the problem of forprofit colleges. The commission's charge involved contacting other state officials across the country. Results from their work and correspondence with Illinois, Maryland, Massachusetts, Michigan, New Jersey, New York, Oregon, and Pennsylvania, among other states, as cited, can be found in the report.

23 Ibid., 38-39.

24 Ibid., 39.

25 Ibid., 1-3, 26, 32, 38-40.

26 John Dale Russell, chancellor and executive secretary of the New Mexico Board of Education Finance, to Francis H. Horn, executive secretary, Department of Higher Education, National Education Association (NEA), June 17, 1952, JBEP.

27 GI Bill amendment of 1946: P.L. 79-679; GI Bill amendment of 1949: P.L. 80-862; GI Bill amendment of 1950: P.L. 91-266; GI Bill amendment of 1950: P.L. 81-610.

28 For reports tracking FPCU fraud at the state level, see Illinois Legislative Council, Statutory Control. For statistics about FPCU students, funding, and institutions nationwide, consult the following federal documents: RETS; Report of the House Select Committee to Investigate Educational and Training Programs Under G.I. Bill, House Report No. 3253 (Washington, DC: GPO, 1951), hereafter HSC 51; General Accounting Office Report of Survey — Veterans' Education and Training Program (Washington, DC: GPO, 1951), hereafter GAO 51.

29 Fine, "Fake Colleges," 1. Approximate dollar amounts calculated using the Consumer Price Index (CPI) data provided by the US Bureau of Labor Statistics, retrieved from http://www.saving.org/inflation.

30 Ibid.

31 See Edmonson correspondence on the topic in box 1, folder "Fraudulent Schools," JBEP.

32 On NEA history, see Wayne Urban's Gender, Race, and the National Education Association: Professionalism and its Limitations (New York: Routledge-Falmer, 2000) and Marjorie Murphy's Blackboard Unions: The AFT and the NEA, 1900-1980 (Ithaca, NY: Cornell University Press, 1992).

33 JBE to Ralph McDonald, May 5, 1949, JBEP; Ralph McDonald to JBE, June 3, 1949, JBEP; Ralph McDonald to JBE, December 7, 1949, JBEP.

34 JBE, "Meeting of the Committee on Fraudulent Schools and Colleges, January 15 and 16, 1950, Washington, DC," JBEP. 
35 William Pencke, “Degrees for Sale,” NEA Journal (April 1949): 287.

36 Ibid., 286.

37 JBE, "To the Committee on Fraudulent Schools and Colleges," JBEP. Edmonson avoided entering the larger disagreements over academic credibility within religious and theological communities. His main goal was to have those institutions with traditional, university-based standing police those without. Edmonson also consistently referred correspondents who asked about the value of one-off Bible colleges to the registrar of the nearest flagship state university to see if credits would transfer. That appeared to serve as his general rule of thumb when it came to ferreting out diploma mills.

38 JBE, "To the Committee on Fraudulent Schools and Colleges," JBEP.

39 JBE, "Meeting of the Committee" and "To the Committee," JBEP.

40 JBE, "Meeting of the Committee," JBEP; John Dale Russell to Ralph McDonald, December 2, 1949, JBEP.

41 William S. Carlson to JBE, February 7 and 13, 1950, JBEP; W. F. Dyde to JBE, February 6, 1950, JBEP; Howard Hunt Pattee to JBE, March 13, 1950, JBEP; Benny B. Hughes to JBE, February 9, 1950, JBEP; S. B. Copeland to JBE, February 20, 1950, JBEP.

42 See, for instance, Philip C. Pack to JBE, February 6, 1950, JBEP; William L. Pencke to JBE, March 2, 1950, September 3 and 20, 1950, October 19, 1950, September 18, 1951, JBEP.

43 I. L. Kandel to JBE, June 15 and 26, 1950, JBEP; James B. Edmonson, "Fraudulent Schools and Colleges," School and Society 72 (July 15, 1950): 33-35.

44 George L. Johnson to JBE, June 18, 1952, JBEP; Harold B. Baker to JBE, September 1 and 26, 1950, JBEP; Harry F. Gay to JBE, March 26, 1952; JBE to Harry F. Gay, April 8, 1952, JBEP.

45 "Some Policies of States Governing the Granting of College Charters and Related Problems," Association of Higher Education, National Education Association, 1953, JBEP. Table 1 is based on the updated and corrected responses discussed in James B. Edmonson, "Responsibility for Diploma Mills," Higher Education (January 1954): 88-89.

46 "Preliminary Draft of a Bill to Provide for Regulatory Licensure of Schools Conducted for Profit in the State of (Purpose: To eliminate fraudulent institutions)," Association of Higher Education, National Education Association, 1953, JBEP. See Pencke, "Degrees for Sale," for more on the precursor to this draft legislation.

47 Edmonson, "Responsibility for Diploma Mills," 88-89.

48 M. A. Nash to JBE, February 21, 1953, JBEP; JBE to M. A. Nash, February 27, 1953 , JBEP; Arthur S. Adams to JBE, July 27, 1953, JBEP; H. D. Hopkins to JBE, February 19, 1954, JBEP.

49 James B. Edmonson, "The Underworld of Education: Degrees and Diplomas Can Be Bought," Michigan Alumnus Quarterly Review 59 (Autumn 1952): 262; Walter Wienert to JBE, March 24, 1953, JBEP; on FPCU statistics, see RETS, 46.

50 Homer Kempfer to JBE, May 14, 1953, JBEP; Charles L. Platt to JBE, May 4, 1953, JBEP; Charles L. Platt to Duke McColl and Earl Cranston, April 3, 1953, JBEP.

51 S. A. Witmer to JBE, May 6, 1953, JBEP; JBE to S. A. Witmer, May 12, 1953, JBEP; S. A. Witmer to JBE, May 26, 1953, JBEP; S. A. Witmer to JBE, November 3, 1953, JBEP.

52 Arthur S. Adams to JBE, July 27, 1953, JBEP. Sample correspondents include officials from the following organizations: Ford Foundation, Western College Association, National Catholic Educational Association, National Association of College Deans and Registrars, National Home Study Council, National Association and Council of Business Schools, US Air Force, US Veterans Affairs, Psychological Corporation, California Department of Education, and dozens of other individual and institutional communications. See letters in box 1, folder "Fraudulent Schools," JBEP. 
RETS, 77.

HSC 52, 3. See also these federal reports on FPCU fraud: HSC 51 and GAO 51.

JBE, "Report of the Committee on Fraudulent Schools and Colleges for 1953," JBEP.

JBE to Francis Horn, May 27, 1952, JBEP; Francis Horn to JBE, May 29, 1952, JBEP;

JBE to Alvin Eurich, May 31, 1952, JBEP.

Alvin Eurich to JBE, June 26, 1952, JBEP.

JBE, "Report of the Committee on Fraudulent Schools and Colleges for 1953," JBEP.

Arthur S. Adams to Harlan H. Hatcher, July 23, 1958, JBEP. On the politics of the Higher Education Act of 1965, see Lawrence Gladieux and Thomas Wolanin, Congress and the Colleges: The National Politics of Higher Education (Lexington, MA: Lexington Books, 1976) and Christopher Loss, Between Citizens and the State: The Politics of American Higher Education in the Twentieth Century (Princeton, NJ: Princeton University Press, 2014).

60 Melanie Hirsch, "What's in a Name? The Definition of an Institution of Higher Education and Its Effect on For-Profit Postsecondary Schools," New York University Journal of Legislation and Public Policy 9 (2006): 817-832.

61 Karl Vick, "Trade Schools Accused of Fraud Still Receive Aid," St. Petersburg Times, November 20, 1988.

62 Abuses in Federal Student Grant Programs: Proprietary School Abuses, Hearing before the Permanent Subcommittee on Investigations of the Committee on Governmental Affairs, US Senate (Washington, DC: GPO, 1995), 57.

63 For-Profit Higher Education: The Failure to Safeguard the Federal Investment and Ensure Student Success, Prepared by the Committee on Health, Education, Labor, and Pensions, US Senate, 4 vols. (Washington, DC: GPO, 2011); Tiffany Stanley, "On For-Profit Colleges, Congress Gets Schooled-Again,” New Republic, October 12, 2010.

64 On the GI Bill, see note 6.

65 Mid-twentieth-century individuals and institutions mentioned as Edmonson allies throughout this article deserve further attention. Of particular interest should be legal, medical, and business associations and their official responses to state-level FPCU lobbying efforts.

66 "Interchange: The History of Capitalism," Journal of American History 101 (2014): 504.

67 See Proctor and Schiebinger, eds., Agnotology.

68 Some scholars tend to see fraud as the work of a minor subset of the for-profit sector. See, for instance, Kevin Kinser, From Main Street to Wall Street: The Transformation of For-Profit Higher Education (Hoboken, NJ: Wiley Periodicals, 2006) and Richard S. Ruch, Higher Ed. Inc.: The Rise of the For-Profit University (Baltimore, MD: Johns Hopkins University Press, 2001).

69 The estimate of the FPCU industry's size is based on calculations drawn from For-Profit Higher Education: The Failure to Safeguard the Federal Investment and Ensure Student Success, Prepared by the Committee on Health, Education, Labor, and Pensions, US Senate, 4 vols. (Washington, DC: GPO, 2011).

70 Sarah Ann Schade, "Reining in the Predatory Nature of For-Profit Colleges," Arizona Law Review 56 (2014); Blake Shinoda, "Enabling Class Litigation as an Approach to Regulating For-Profit Colleges," Southern California Law Review 87 (2014); Daniel J. Riegel, "Closing The 90/10 Loophole in the Higher Education Act: How to Stop Exploitation of Veterans, Protect American Taxpayers, and Restore Market Incentives to the For-Profit College Industry," George Washington Law Review 81 (2013);

Amanda Harmon Cooley and Aaron Cooley, "The Need For Legal Reform of the ForProfit Educational Industry,” Tennessee Law Review 79 (2012); Osamudia R. James, "Predatory Ed: The Conflict between Public Good and For-Profit Higher Education," Journal of College and University Law 38 (2011): 45-105. 